\title{
Serological and Molecular Detection of Chicken Anemia Virus in Broiler and Layer Chickens in Iraq
}

\author{
Karim Sadun Al-Ajeeli, Amer Khazaal Al-Azawy* and Haneen Ghazuan \\ Department of Microbiology, College of Veterinary Medicine, University of Diyala, Iraq. \\ *Corresponding author's E-mail: amer_alazawy@yahoo.com; ORCID: 0000-0002-4422-5442
}

Received: 29 Dec. 2019

Accepted: 11 Feb. 2020

\begin{abstract}
Chicken Anemia Virus (CAV) infects many bird species worldwide and causes immunosuppression. This condition can facilitate the infection of affected birds with other pathogens including bacteria, viruses, and fungi. No data were available on detection or isolation of CAV from birds in Iraq, therefore this study was designed to detect CAV antibodies in broilers and layers in some poultry farms. Accordingly, 200 samples were collected from broiler and layer farms (100 samples each) from different districts of Diyala province and subjected to the ELISA test. Also, 50 tissue samples from embryonated eggs from different hatcheries, four commercial viral vaccines, and 30 ELISA positive samples were subjected to PCR assay to detect the CAV DNA. The results showed that all of broiler and layer farms sampled were serologically positive for CAV antibodies. The overall seropositivity for CAV antibodies for both chicken breeds was 51.5\%. In broilers, 43 out of 100 serum samples were positive for CAV antibodies, whereas 60 out of 100 serum samples from layers were CAV antibody-positive. According to age groups, significant differences were observed among one-week-old broilers (30.2\%) compared to other age groups. In layers, the age group of 30 weeks showed a seropositivity rate of $33.3 \%$. Conventional PCR test indicated that all tissue samples collected from suspected birds and embryonated eggs were negative for CAV DNA, but only 2 out of 30 serum samples were PCR positive. It is concluded that CAV is endemic in poultry farms of Iraq and may facilitate the vaccination failure against other viruses.
\end{abstract}

Key words: Broilers, Chicken anemia virus, ELISA, Layers, PCR

\section{INTRODUCTION}

Chicken Anemia Virus (CAV) infection is an important disease from economic and health points of view in the poultry industry worldwide (Bhatt et al., 2011; Padhy et al., 2015; Adedeji et al., 2016). The CAV is a singlestranded circular negative sense DNA virus. It is the smallest among DNA viruses and classified within the genus Gyrovirus in the family Anelloviridae (Li et al., 2017a; Rosario et al., 2017). The virus DNA encodes viral proteins of VP1, VP2, and VP3 (Ducatez et al., 2008). This virus causes chicken anemia or blue wing disease in many species of birds (Mariya, 2018).

The CAV was first isolated from affected chicks in Japan in 1979, but Toro et al. (2006) by analyzing stock serums, reported that the virus has been circulated in the USA since 1959. Although the infection is contagious, most affected birds with CAV are aged 7 to 28 days, which shows atrophy of lymphoid tissues and severe anemia (Dhama et al., 2008). Birds infected with CAV are susceptible to infection with other pathogens as the virus causes immunosuppression and results in vaccination program failure (De Herdt et al., 2001; Hoerr, 2010; Rimondi et al., 2014). Mortality, secondary infections, and poor weight gain due to $\mathrm{CAV}$ infection lead to economic losses (Dhama et al., 2008).

The causative agent of the disease can be transmitted by two modes (Miller et al., 2003; Brentano et al., 2005), vertical (Cardona et al., 2000a) or horizontal transmission through oral-fecal route and infected feather's shaft (Davidson et al., 2008). Some studies have detected antibodies against CAV in specific-pathogen-free chickens, supporting the hypothesis of latent or persistent CAV infections. It is suggested that the virus persists in the reproductive system and it may be somehow reactivated (Cardona et al., 2000b; Miller and Schat 2004; Miller et al., 2008).

In case of active infections, it is recommended to depend on clinical findings for CAV diagnosis. 
Furthermore, this can be confirmed by many serological tests such as immunofluorescent antibody test, EnzymeLinked Immunosorbent Assay (ELISA) and virus neutralization using reference serum (Todd et al., 2001), hemagglutination inhibition test, agar gel precipitation test (Kataria et al., 2013) and indirect immunofluorescent test (Oluwayelu et al., 2007) or by virus isolation using cell culture (Van Santen et al., 2001). Many molecular techniques such as Polymerase Chain Reaction (PCR), whole-genome sequencing, and restriction fragment length polymorphism are used for epidemiological studies or differentiation between virus isolates of CAV (Schat, 2009; Manoharan et al., 2012; Rehman et al., 2018).

In Iraq, no data were available on screening of chicken commercial farms for presence of CAV infection; there is only one report on CAV seropositivity in Japanese quails and local fowls (Al-Ajeeli et al., 2018). Accordingly, the present study aimed to investigate the presence of CAV antibodies in broiler and layer chickens and to detect CAV DNA in positive serum samples, embryonated eggs from different hatcheries, and some commercial viral vaccines.

\section{MATERIALS AND METHODS}

This study was conducted in virology and molecular biology laboratories of the College of Veterinary Medicine, University of Diyala, Iraq over the period from October 2017 to July 2018.

\section{Ethical approval}

Scientific ethical committee in the University of Diyala/ College of Veterinary Medicine, Iraq, approved the research and give the ethical number (Vet 24 Medicine November 2017 K, A and H).

\section{Serum samples}

A total of 200 blood samples were collected from five commercial broiler farms aged 1-5 weeks old (100 samples) and four layer farms aged 8-30 weeks old (100 samples) in different areas of Diyala province, Iraq. Blood sampling was performed by wing vein puncture using sterile syringes and vacuum blood collection tubes gel clot activator (UNIMEDIC, Iraq). Then sera were separated and placed in Eppendorf sterile tube, labeled and centrifuged at $1500 \mathrm{rpm}$ for 5 minutes (Cold Eppendorf centrifuge. THERMO FISHER, USA). The supernatant was collected from each sample and transferred to another sterile Eppendorf tube and stored at $-20{ }^{\circ} \mathrm{C}$ until used.

\section{Processing of samples for ELISA}

The sera (1:10 dilution) were tested using a commercial ELISA kit (IDEXX Lab, Germany). Optical density values were read at $650 \mathrm{~nm}$ using the ELX $800^{\mathrm{TM}}$ microplate reader (BIO-TEK Instruments, USA) and data were expressed as $\mathrm{S} / \mathrm{N}$ ratio (sample to negative ratio). Samples with $\mathrm{S} / \mathrm{N}>0.60$ were considered negative for CAV antibodies, whereas samples with $\mathrm{S} / \mathrm{N} \leq 0.60$ were considered positive for $\mathrm{CAV}$ antibodies.

\section{PCR samples}

PCR samples included 50 embryonated hen eggs (10 days old) collected from five different hatcheries in Diyala province, 30 CAV-ELISA positive serum samples randomly selected, and four available commercial viral vaccines against Newcastle disease, infectious bronchitis, and infectious bursal disease (Gumboro) (Table 1). These samples were subjected to DNA extraction before testing by PCR.

\section{DNA extraction}

DNA extraction was carried out using a DNA extraction kit (Genekam Biotechnology AG, Germany) according to the instructions of the manufacturer.

Table 1. Commercial vaccine samples used for detection of chicken anemia virus by PCR assay.

\begin{tabular}{lcc}
\hline Vaccines & Dose & Country \\
\hline Nobilis $®$ Gumboro D78 (live) & 1000 & Netherlands \\
Nobilis $®$ MA5 + CLONE 30 (live) / against Massachusetts type of IB and ND & 1000 & Netherlands \\
Nobilis $®$ ND clone 30 (live) & 1000 & Netherlands \\
Nobilis $®$ IB 4-91 (live attenuated) & 1000 & Netherlands \\
\hline
\end{tabular}

IB: Infectious bronchitis, ND: Newcastle disease

\section{PCR procedure}

To detect the presence of CAV DNA in the abovementioned samples, PCR kit (Genekam Biotechnology
AG: Ref.K132, Germany) was used according to the manufacturer's instructions. This PCR commercial kit has been designed to produce a CAV DNA fragment of 675 
base pairs (bp) from the gene responsible for VP1 production (VP1 gene).

The PCR thermal cycle included a heating step at $94^{\circ} \mathrm{C}$ for 300 seconds, and the amplification cycle that included denaturing step at $94^{\circ} \mathrm{C}$ for 60 seconds, annealing step at $50^{\circ} \mathrm{C}$ for 60 seconds, extension step at $72^{\circ} \mathrm{C}$ for 120 seconds. This cycle was repeated 35 times and followed by a long extension step at $72^{\circ} \mathrm{C}$ for 600 seconds. The product was cooled to $4{ }^{\circ} \mathrm{C}$ and kept at $-20{ }^{\circ} \mathrm{C}$ until electrophoresed in $2 \%$ agarose gel in $1 \mathrm{x}$ TAE buffer along with molecular weight marker, stained with ethidium bromide $(0.05 \mu \mathrm{g} / \mathrm{ml})$ and photographed.

\section{Statistical analysis}

The results were statistically analyzed using SPSS version 21. P-values less than 0.05 were considered significant.

\section{RESULTS}

\section{Seropositivity rate of chicken anemia virus in broiler chickens}

The overall seropositivity rate for CAV in broilers was $43 \%$. According to age groups, there were significant differences in seropositivity between groups of two weeks old $(9.3 \%)$ and five weeks old $(16.3 \%)$ with groups of one
$(30.2 \%)$, three $(20.9 \%)$ and four weeks old $(23.3 \%)$. The significant differences were observed in the number of seropositive samples to the number of seronegative samples of age groups of one, two and four weeks (Table 2).

\section{Seropositivity rate of chicken anemia virus in layer chickens}

The overall seropositivity rate for CAV in layers was $60 \%$. The age group of 30 weeks old showed a seropositivity rate of $33.3 \%$, followed by a seropositivity rate of $31.7 \%, 26.7 \%$ and $8.3 \%$ for the age groups of 28,8 and 10 weeks, respectively. Significant differences appeared between positive and negative serum samples of each age group. Also, significant differences appeared between the age group of 10 weeks and other age groups in both positive and negative serum samples (Table 3 ).

\section{Seropositivity rate for chicken anemia virus according to chicken breeds \\ The results showed differences in seropositivity} among both groups of chicken breeds (layers and broilers). In broilers, 43 (43\%) samples were positive for CAV antibodies. In layers, $60(60 \%)$ serum samples were positive for CAV antibodies. Significant differences were observed between the seropositivity of broilers' serum samples and that of layers' serum samples (Table 4).

Table 2. Seropositivity rate for antibodies against chicken anemia virus in broiler chickens of different ages

\begin{tabular}{|c|c|c|c|}
\hline Age of birds & $\begin{array}{c}\text { No of CAV-ab positive } \\
\text { samples }\end{array}$ & $\begin{array}{c}\text { No of CAV-ab negative } \\
\text { samples }\end{array}$ & Total \\
\hline One week & $13^{\mathrm{a}}$ & $7^{\mathrm{b}}$ & 20 \\
\hline Two weeks & $4^{\mathrm{b}}$ & $16^{\mathrm{a}}$ & 20 \\
\hline Four weeks & $10^{\mathrm{a}}$ & $10^{\mathrm{a}}$ & 20 \\
\hline Five weeks & $7^{\mathrm{b}}$ & $13^{\mathrm{a}}$ & 20 \\
\hline
\end{tabular}

Different superscript letters in a column indicate significant differences $(\mathrm{p}<0.05)$. CAV-ab: chicken anemia virus antibody, No: Number

Table 3. Seropositivity rate for antibodies against chicken anemia virus in layers chickens of different ages

\begin{tabular}{lccc}
\hline Age of birds & $\begin{array}{c}\text { No of CAV-ab positive } \\
\text { samples }\end{array}$ & $\begin{array}{c}\text { No of CAV-ab negative } \\
\text { samples }\end{array}$ & Total \\
\hline 8 weeks & $16^{\mathrm{a}}$ & $9^{\mathrm{b}}$ & 25 \\
10 weeks & $5^{\mathrm{b}}$ & $20^{\mathrm{a}}$ & 25 \\
28 weeks & $19^{\mathrm{a}}$ & $6^{\mathrm{b}}$ & 25 \\
30 weeks & $20^{\mathrm{a}}$ & $5^{\mathrm{b}}$ & 25 \\
Total & $60^{\mathrm{a}}$ & $40^{\mathrm{b}}$ & 100 \\
\hline
\end{tabular}

Different superscript letters in a column indicate significant differences ( $\mathrm{p}<0.05)$. CAV-ab: chicken anemia virus antibody, No: Number

Table 4. Seropositivity rate for antibodies against chicken anemia virus in layer and broiler chickens

\begin{tabular}{|c|c|c|c|}
\hline Age of birds & $\begin{array}{c}\text { No of CAV-ab positive } \\
\text { samples }\end{array}$ & $\begin{array}{c}\text { No of CAV-ab negative } \\
\text { samples }\end{array}$ & Total \\
\hline Layers & $60^{\mathrm{b}}$ & 40 & 100 \\
\hline
\end{tabular}




\section{Level of chicken anemia virus antibodies}

The level of antibodies in broiler serum samples appeared high $(\mathrm{H})$ in $13 \%$ of samples, medium $(\mathrm{M})$ in $11 \%$ and low (L) in 19\% of samples, whereas 57 (57\%) samples were negative for CAV antibodies. In layers, $29 \%$ were $\mathrm{H}$, $19 \%$ samples were $\mathrm{M}$, and $12 \%$ were $\mathrm{L}$, whereas, $40 \%$ of samples were negative. There were significant differences among $\mathrm{H}$ level and $\mathrm{L}$ level of layers. The number of negative samples for CAV antibodies according to the S/N ratio was 97 samples (57 from broilers and 40 from layers). Significant differences $(\mathrm{p}<0.05)$ appeared between the number of negative serum samples collected from broilers $(57 \%)$ and negative serum samples collected from layers (40\%). Significant differences were also observed in number of CAV-positive broiler serum samples of $\mathrm{H}$ (13), M (11), and L (19) S/N ratio with those of H (29), M (19), and L (12) S/N ratio in layers, respectively (Table 5).

\section{Detection of chicken anemia virus DNA by PCR assay}

All 50 tissue samples collected from embryonated eggs and four commercial virus vaccines were negative for CAV DNA using PCR test. Out of 30 tested sera, only two serum samples were positive for CAV DNA using PCR that resulted in a PCR fragment of 850 base pairs (Figure 1).

Table 5. Antibody levels to chicken anemia virus in different chicken breeds.

\begin{tabular}{lccc}
\hline Range of S/N ratio & Broilers & Layers & Total \\
\hline High $(0.001$ to 0.199$)$ & $13^{\mathrm{a}}$ & $29^{\mathrm{b}}$ & 42 \\
Medium $(0.200$ to 0.399$)$ & $11^{\mathrm{a}}$ & $19^{\mathrm{b}}$ & 30 \\
Low $(0.400$ to 0.599$)$ & $19^{\mathrm{b}}$ & $12^{\mathrm{a}}$ & 31 \\
Negative $(0.600$ and above) & $57^{\mathrm{a}}$ & $40^{\mathrm{b}}$ & 97 \\
Total & 100 & 100 & 200 \\
\hline
\end{tabular}

Different superscript letters in a column indicate significant differences $(\mathrm{p}<0.05)$. $\mathrm{S} / \mathrm{N}$ ratio: Sample to Negative ratio

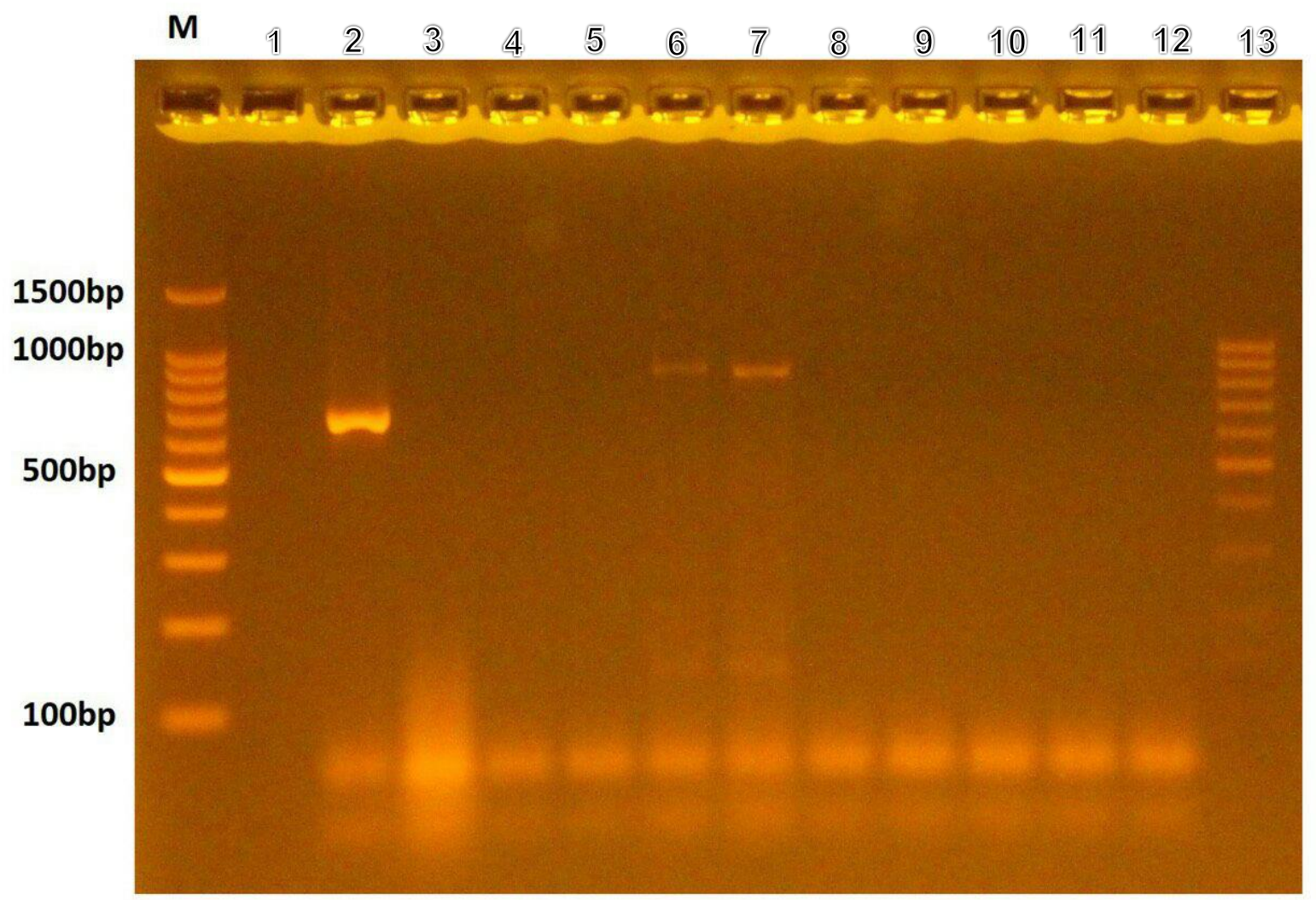

Figure 1. Results of CAV-ELISA positive serum samples subjected to PCR. Lane M (molecular weight markers), Lane 1 (negative control), Lane 2 (positive control, 675 bp), Lanes 3, 4, 5, 9, 10, 11 and 12 (negative serum samples), Lanes 6 and 7 (positive serum samples, 850 bp), Lane 13 (molecular weight markers). 


\section{DISCUSSION}

\section{Seropositivity rate of chicken anemia virus among broilers}

The present study showed an overall seropositivity rate of $43 \%$ for CAV antibodies in broilers from different farms of Diyala province. Similar findings were reported from the Central African Republic and Cameroon by Snoeck et al. (2012) who found that 147 out of 400 $(36.75 \%)$ chicken serum samples were positive for CAV antibodies. Furthermore, they found that the seropositivity of birds to CAV antibodies was different according to age groups and ranged from $25 \%$ to $50 \%$, and most positive cases were reported in age groups of 4 to 10 weeks old. In the present study, the majority of positive cases were in ages ranged from three to five weeks. Similar findings were reported in Malaysia (Oluwayelu et al., 2008), India (Bhatt et al., 2011) and China (Zhou et al., 1996). A seropositivity rate ranged from $66-100 \%$ was reported in Hungary by Drén et al. (1996).

The low seropositivity rate of CAV antibodies obtained in the present study is in agreement with the speculation of De Herdt et al. (2001) who mentioned that a particular chicken flock might not show homogenous seropositivity rate because the number of positive cases for CAV antibodies increases with age. Similar findings in association of seropositivity rate with increasing age of birds were reported by Owoade et al. (2004) who mentioned $40 \%$ seropositivity rate for CAV antibodies among broilers in Nigeria aged 2-6 weeks. Seroprevalence more than that of the present study was reported in many other countries; $49 \%$ in Argentina (Craig et al., 2009), $80 \%$ in Malaysia (Hailemariam et al., 2008) and $87 \%$ in China (Ducatez et al., 2008).

In Iraq, there was no vaccination program against CAV for broilers, but it seems that CAV is widely distributed among broilers. The seropositivity rate of CAV in unvaccinated broilers was also documented by Bidin et al (2010) who reported a seropositivity rate of $94.7 \%$ for CAV antibodies when 54 out of 57 samples collected from breeders were positive for CAV antibodies using ELISA assay. The same authors found that 24 out of $90(26.6 \%)$ serum samples collected from broilers were positive for CAV antibodies. The seropositivity rate in unvaccinated birds aged 4 weeks and above was attributed to horizontal transmission of CAV that may not lead to clinical cases (Bidin et al., 2010). Furthermore, it was suggested that immunization of broilers with infectious bursal disease and Marek's disease viruses indirectly protect them from immune suppression observed in cases of CAV active infections (Bidin et al., 2010).

\section{Seropositivity rate of chicken anemia virus among} layers

In the present study, an overall seropositivity rate of $60 \%$ for CAV in layers was found. Similar findings to the seropositive rate of $\mathrm{CAV}$ in layers were reported by Abdelfattah (2009) who mentioned a seropositivity rate of $67.3 \%$ for CAV in layers in Sudan. Hadmili et al. (2008) reported a seroprevalence of $70.9 \%$ among layer groups in Turkey. The same authors found that 15 out of 16 layer groups were positive for CAV antibodies. In the present study, all layer farms tested were positive for CAV antibodies. Ballal et al. (2005) also reported that all tested layer groups in Sudan were positive for CAV antibodies. In the present study, the high seropositivity rate for CAV was detected in age groups of 28-30 weeks. This finding is consistent with previous findings that indicated an increase in seropositivity rate at older ages (Owoade et al., 2004; Sharma et al., 2014).

\section{Detection of the chicken anemia virus DNA}

PCR was used as a diagnostic tool for the detection of CAV in samples collected from birds suspected to be infected by the virus (Abo-Elkhair et al., 2014; Simeonov et al., 2014; Eskandarzade et al, 2015; Al-Kateb et al., 2017). Hailemariam et al. (2008) found that $40-70 \%$ of tested chicken embryos were positive for CAV when tested by PCR. However, the results obtained in the present study indicated that all embryonated tissue samples were negative for CAV. It seemed that it was dependable on the source of egg supply. The five hatcheries sampled in the present study were received their fertile eggs from one source supplier.

In the present study, the detection of CAV DNA in four commercial vaccines revealed that all used poultry commercial viral vaccines were negative for CAV. This finding is inconsistent with findings of Li et al. (2017b) who reported two batches of live viral vaccines were positive for CAV DNA in comparison to 12 negative batches of the vaccines in China, and also with findings of Varela et al. (2014) who found that 6 out of 32 tested live viral vaccines were positive for CAV DNA and 1 out of 3 inactivated viral vaccines were also positive for the virus using PCR. The negativity of PCR detection in commercial vaccines in this study may be attributed to the small size of sampling (only four vaccines) in addition to these samples were from one company. 
In the present study, CAV DNA was detected in 2 out of 30 tested serum samples. This result is in agreement with the findings of Tham and Stanislawek (1992), who detected the CAV DNA in two serum samples out of 37 PCR tested sera. This could be attributed to circulating CAV antibodies that might clear the virus from the blood circulation of infected birds and accordingly could not be detected by PCR. The PCR fragment that produced from two positive serum samples of present study was of $850 \mathrm{bp}$ but the DNA fragment that should be detected by the PCR kit was assumed as $675 \mathrm{bp}$, and this difference in molecular weight of detected DNA fragment of present study and the assumed fragment's molecular weight of CAV DNA may be attributed to genetic variation among the locally detected CAV.

Many studies reported genetic variations among CAV isolates (Van Santen et al., 2007; Mohamed, 2010; Eltahir, et al., 2011; Hussein et al., 2016) that supports the finding of present study that the detected DNA PCR fragment of $850 \mathrm{bp}$ rather than $675 \mathrm{bp}$ of PCR kit might be attributed to genetic variation that allows the production of different DNA fragment size.

Oluwayelu et al. (2008) reported genetic differences among Nigerian CAV isolates that grouped them into four clusters. Hailemariam et al. (2008) described genetic variation in Malaysian CAV isolates due to genetic substitutions in DNA nucleotide bases resulted in changing of amino acid positions of VP1 in amino acid 75, 97,139 and 144 that led to group the isolates into two groups. Zhang et al. (2013) recorded strong evidence of genetic recombination in coding and non-coding regions of whole CAV genome in different Chinese isolates.

\section{CONCLUSIONS}

In conclusion, the detection of antibodies against chicken anemia virus in broilers and layers demonstrated that this virus widely distributes in poultry farms of Diyala province, Iraq. This condition requires restricted and effective control measures to avoid the possibility of complicated infections and vaccination failure as the virus causes immune suppression in infected birds.

\section{DECLARATIONS}

\section{Acknowledgments}

We would like to thank the staff members of the college's poultry farm and the experimental animal hall for their help. We also acknowledge the College of Veterinary Medicine University of Diyala for logistic supports.

\section{Author's contribution}

Karim Sadun Al-Ajeeli and Amer Khazaal A-Azawy proposed the hypothesis, designed the study and conducted the serological and molecular works. Haneen Ghazuan collected samples from poultry farms. All authors contributed to manuscript preparation and approved the final manuscript.

\section{Competing interests}

The authors declare that they have no competing interests.

\section{REFERENCES}

Abdelfattah IEA (2009). Serological survey of CAV in Khartoum State, Sudan. M.Sc. thesis, Department of Preventive Medicine and Veterinary Public Health, Faculty of Veterinary Medicine, University of Khartoum. pp.27-42.

Abo-Elkhair M, Abd El-Razak AG and Metwally AEY (2014). Molecular characterization of CAV circulating in chicken group in Egypt. Advances in Virology, 2014: 797151. DOI: http://dx.doi.org $/ 10.1155 .2014 / 797151$

Adedeji AJ, Sati N, Pewan S, Ogbu K, Adole J, Lazarus D, Ijiwo S, Okpanachi A, Nwagbo I and Joannis T (2016). Concurrent infections of chicken infectious anemia and infectious bursal disease in 5 weeks old pullets in Jos, Plateau State, Nigeria. Veterinary Sciences: Research and Reviews, 2(3): 60-65. DOI: http://dx.doi.org/10.17582/journal.vsrr/2016.2.3.60.65 .

Al-Ajeeli KS, Al-Azawy AK and Al-Rubayee H (2018). Seroprevalence of chicken anemia virus in local fowls and Japanese quails. Indian Journal of Natural Sciences, 9 (51):15691-15699.

Al-Kateb A, Mansour L, Skeeb A, Al-Khallab E, Dardour A and Gerish EKH (2017). Molecular detection of chicken infectious anemia virus from backyard chickens in Libya. AlQalam Journal of Medical and Biological Research, 1(1): 70-75. Available at: https://www.researchgate.net/publication/331635917 .

Ballal A, Elussein AM and Igbal ASA (2005). Serological survey of chicken infectious anemia in commercial group in Khartoum state, Sudan. Journal of Animal and Veterinary Advances, 4(7):666-667.

Bhatt P, Shukla S K, Mahendran M, Dhama K, Chawak MM and Kataria JM (2011). Prevalence

Biđin M, Savić V, Biđin Z, Balenović M and Majnarić D (2010). The prevalence of antibodies against CAV in unvaccinated broilers and broiler breeders in Croatia. Veterinarski Archiv, 80(6): 753-760. Available at: https://hrcak.srce.hr/62391

Brentano L, Lazzarin S, Bassi SS, Klein TAP and Schat KA (2005). Detection of CAV in the gonads and in the progeny of broiler breeder hens with high neutralizing antibody titers. Veterinary Microbiology, 105(1): 65-73. DOI: https://doi.org/10.1016/j.vetmic.2004.09.019.

Cardona C, Lucio B, O'Connell P, Jagne J and Schat KA (2000b). Humoral immune responses to chicken infectious anemia virus in three strains of chickens in a closed flock. Avian Diseases, 44(3): 661-667. DOI: https://doi.org/10.2307/1593108 .

Cardona CJ, Oswald WB and Schat KA (2000a). Distribution of chicken anaemia virus in the reproductive tissues of specific-pathogen-free chickens. Journal of General Virology, 81(8): 2067-2075. DOI: https://doi.org/10.1099/0022-1317-81-8-2067 .

Craig MI, Rimondi A, Delamer M, Sansalone P, König G, Vagnozzi A and Pereda A (2009). Molecular characterization of chicken infectious anemia virus circulating in Argentina during 2007. Avian Diseases, 53(3): 331-335. DOI: https://doi.org/10.1637/8932.1 . 
Davidson I, Artzi N, Shkoda I, Lublin A, Loeb E and Schat KA (2008). The contribution of feathers in the spread of CAV. Virus Research, 132(1-2): 152-159. DOI: https://doi.org/10.1016/j.virusres.2007.11.012 .

De Herdt P, Bosch V, Ducatelle R, Uyttebroek E and Schrier C (2001). Epidemiology and significance of chicken anemia virus infections in broilers and broiler parents under nonvaccinated European circumstances. Avian Diseases, 45(3):706-708. Available at: https://www.jstor.org/stable/1592916?origin=JSTOR-pdf\&seq=1

Dhama K, Mahendran M, Somvanshi R and Chawak MM (2008). Chicken infectious anemia virus: an immunosuppressive pathogen of poultry-a review. Indian Journal of Veterinary Pathology, 32(2): 158-167. DOI: https://doi.org/10.1017/S0043933914000828 .

Drén C, Farkas T and Németh I (1996). Serological survey on the prevalence of chicken anaemia virus infection in Hungarian chicken group. Veterinary Microbiology, 50(1-2): 7-16. DOI: https://doi.org/10.1016/0378-1135(96)00002-8 .

Ducatez MF, Chen H, Guan Y and Muller CP (2008). Molecular epidemiology of CAV in southeastern Chinese live birds markets. Avian Diseases, 52(1): 68-73. DOI: https://doi.org/10.1637/8049-070407-reg .

Eltahir YM, Qian K, Jin W, Wang P and Qin A (2011). Molecular epidemiology of CAV in commercial farms in China. Virology Journal, 8:145-152. DOI: https://doi.org/10.1186/1743-422x-8-145 .

Eskandarzade N, Heydarnezhad A, Valizadeh Y,Shokouhi M and Kholenjani AS (2015). Molecular detection of CAV from native Larry-breed chickens in Charmahal-va-Bakhtiyari province, Iran. International Journal of Medical Laboratory, 2(2):105-111. DOI: https://doi.org/10.1016/j.meatsci.2014.02.007 .

Hadmili HH, ERGANIŞS O, Güler L and Ucan US (2008). Investigation of chicken infectious anemia virus infection by PCR and ELISA in chicken group. Turkish Journal of Veterinary and Animal Sciences, 32(2): 79-84.

Hailemariam Z, Omar AR, Hair-Bejo M and Giap TC (2008). Detection and characterization of CAV from commercial broiler breeder chickens. Virology Journal, (5): 128-138. DOI: https://doi.org/10.1186/1743-422x-5-128 .

Hangood LT, Kelly TF, Wright JC and Hoerr FJ (2000). Evaluation of chicken infectious anemia virus and associated risk factors with disease and production losses in broilers. Avian Diseases, (44): 803-808. DOI: https://doi.org/10.2307/1593052 .

Hoerr FJ (2010). Clinical aspects of immune suppression in poultry. Avian Diseases, 54(1): 2-15. DOI: https://doi.org/10.1007/978-1-4615-7237-4 .

https://doi.org/10.1111/j.1865-1682.2011.01215.x .

Hussein E, Arafa AE, Anwar N and Khafaga A (2016). Molecular and pathological analysis of CAV isolated from field infection in three Egyptian Provinces. Advances in Animal and Veterinary Sciences, 4(5): 218-229. DOI: https://doi.org/10.14737/journal.aavs/2016/4.5.218.229 .

Kataria JM, Dham K, Nagarajan S, Chakraborty S, Kaushal A and Deb R (2013). Fowl adenoviruses causing hydropericardium syndrome in poultry. Advances in Animal and Veterinary Sciences, 1(48):5-13.

Li Y, Fang L, Cui S, Fu J, Li X and Zhasng H (2017a). Genomic characterization of recent chicken anemia virus isolates in China. Frontiers in Microbiology, 8: 401-410. DOI: https://doi.org/10.3389/fmicb.2017.00401 .

Li Y, Hu, Y, Cui S, Fu J, Wang Y, Cui Z, Fang L, Chang S and Zhao P (2017b). Molecular characterization of chicken infectious anemia virus from contaminated live-virus vaccines. Poultry Science, 96(5): 1045-1051. DOI: https://doi.org/10.3382/ps/pew406 .

Manoharan AS, Ramadass P and Kumanan K (2012). Assessment of polymerase chain reaction sensitivity for the detection of chicken anaemia virus using different primers for three genes. Veterinarski Arhiv, 82(1): 89-102. Available at: https://hrcak.srce.hr/77406 .
Mariya H (2018). Blue wing disease. Approaches in Poultry Dairy and $\begin{array}{lll}\text { Veterinary } & \text { Sciences, } & 5(2): 407-408 .\end{array}$ https://doi.org/10.1080/03079458408418503 .

Miller MM and Schat KA (2004). Chicken infectious anemia virus: An example of the ultimate host-parasite relationship. Avian Diseases, 48(4): 734-745. DOI: https://doi.org/10.1637/7271090304r .

Miller MM, Ealey KA, Oswald WB and Schat KA (2003). Detection of CAV DNA in embryonal tissues and eggshell membranes. Avian Diseases, 47(3): 662-671. DOI: https://doi.org/10.1637/7007 .

Miller MM, Jarosinski KW and Schat KA (2008). Negative modulation of the chicken infectious anemia virus promoter by COUP-TF1 and an E box-like element at the transcription start site binding $\delta$ EF1. Journal of General Virology, 89(12): 2998-3003. DOI: https://doi.org/10.1099/vir.0.2008/003103-0 .

Mohamed MA (2010). Chicken infectious anemia status in commercial broiler chickens group in assiut-upper Egypt: occurrence, molecular analysis using PCR-RFLP and apoptosis effect on affected tissues. International Journal of Poultry Science, 9(6): 591-598. DOI: https://doi.org/10.3923/ijps.2010.591.598 .

of chicken infectious anemia virus (CIAV) in commercial poultry group of Northern India: a serological survey. Transboundary and Emerging Diseases, 58(5): 458-460.DOI:

Oluwayelu DO, Olaleye OD, Todd D, Emikpe BO and Ohore OG (2007). Evaluation of diagnostic performance and adoption of indirect immunofluorescence for serodiagnosis of chicken infectious anaemia in Nigerian poultry. Tropical Veterinarian, 25 (2): 41-47. DOI: https://doi.org/10.1016/0732-8893(88)90035-1 .

Oluwayelu DO, Todd D and Olaleye OD (2008). Sequence and phylogenetic analysis of chicken anaemia virus obtained from backyard and commercial chickens in Nigeria. Onderstepoort Journal of Veterinary Research, 75(4): 353-357. DOI: https://doi.org/10.4102/ojvr.v75i4.111 .

Owoade AA, Oluwayelu DO, Fagbohun OA, Ammerlaan W, Mulders MN and Muller CP (2004). Serologic evidence of chicken infectious anemia in commercial chicken group in southwest Nigeria. Avian Diseases, 48(1): 202-205. DOI: https://doi.org/10.1637/7075 .

Padhy A, Sahu A, Sahoo S and Ganguly S (2015). Chicken Infectious Anemia: A Review on its Potential Threat to Poultry Industry Worldwide. World Journal of Biology and Medical Sciences, 2(4): 17-19. DOI: https://doi.org/10.1002/9781119421481.ch8 .

Rehman SU, Saleemi M, Khan M, Khan A, Shahzad A, Khatoon A, Fayyaz A, Aslam B, Sajid M, Akhtar M and Abbas R (2018). Molecular epidemiology and pathology of chicken infectious anemia in day old broiler chicks in Faisalabad, Pakistan. International Journal of Agriculture and Biology, 20: 57-61.

Rimondi A, Pinto S, Olivera V, Dibárbora M, Pérez-Filgueira M, Isabel M and Pereda A (2014). Comparative histopathological and immunological study of two field strains of chicken anemia virus. Veterinary Research, 45:102. DOI: https://doi.org/10.1186/s13567014-0102-y .

Rosario K, Breitbart M, Harrach B, Segales J, Delwart E, Biagini P and Varsani A (2017). Revisiting the taxonomy of the family Circoviridae: establishment of the genus Cyclovirus and removal of the genus Gyrovirus. Archives of Virology, 162(5): 1447 - 1463. DOI: https://doi.org/10.1007/s00705-017-3247-y .

Schat KA (2009). Chicken anemia virus. Current Topics in Microbiology and Immunology, 331:151-183. Available at: http://www.springer.com/west/home/generic/search/results .

Sharma RN, Tiwari K, Chikweto A, Thomas D, Stratton G and Bhaiyat MI (2014). Serological evidence of chicken infectious anemia in layer and broiler chickens in Grenada, West Indies. Veterinary World, 7:59-61. DOI: https://doi.org/10.14202/vetworld.2014.59-61 
Simeonov KB, Petrova RT, Gyurov BI, Peshev RD and Mitov BK (2014). Isolation and PCR identification of CAV infection in Bulgaria. Journal of Veterinary Medicine, 17(4):276-284.

Snoeck CJ, Giscard FK, Bonya PM, Emmanuel N, Alain LF, Mbah PO and Muller CP (2012). Epidemiology of CAV in Central African Republic and Cameroon. Virology Journal, 9:189-199. DOI: https://doi.org/10.21236/ada198234.

Tham KM and Stanislawek WL (1992). Polymerase chain reaction amplification for direct detection of CAV DNA in tissues and sera. Avian Diseases, 36(4): 1000-1006. DOI: https://doi.org/10.2307/1591561 .

Todd D, McNulty MS, Adair BM and Allan GM (2001). Animal circoviruses. Advances in Virus Research, 57:1-72. DOI: https://doi.org/10.1016/s0065-3527(01)57000-1 .

Toro H, Ewald S and Hoerr FJ (2006). Serological evidence of chicken infectious anemia virus in the United States at least since 1959. Avian Diseases, 50(1): 124-126. DOI: https://doi.org/10.1637/7442-092205r.1

Van Santen VL, Li L, Hoerr FJ and Lauerman LH (2001). Genetic characterization of CAV from commercial broiler chickens in
Alabama. Avian Diseases, $45(2)$ : 373-388. DOI: https://doi.org/10.2307/1592977 .

Van Santen VL, Toro H and Hoerr FJ (2007). Biological characteristics of CAV regenerated from clinical specimen by PCR. Avian Diseases, 51(1): 66-77. DOI: https://doi.org/10.1637/00052086(2007)051[0066:bcocav]2.0.co;2 .

Varela APM, dos Santos HF, Cibulski SP, Scheffer CM, Schmidt C, Lima FES, Silva AD, Esteves PA, Franco AC and Roehe PM (2014). CAV and avian gyrovirus 2 as contaminants in poultry vaccines. Biologicals, 42(6): 346-350. DOI: https://doi.org/10.1016/j.biologicals.2014.08.002 .

Zhang X, Liu Y, Wu B, Sun B, Chen F, Ji J, Ma J and Xie Q (2013). Phylogenic and molecular characterization of CAV in southern China from 2011- 2012. Scientific Reports, (3): 3519-3525. DOI: https://doi.org/10.1038/srep03519.

Zhou W, Yang B, Shen B, Han S and Zhou J (1996). A serologic survey of antibody against chicken infectious anemia virus by indirect immunofluorescent assay in domestic poultry in China. Avian Diseases, 40(2): 358-360. DOI: https://doi.org/10.2307/1592232. 